\title{
Molecular Genotyping of Human Papilloma Virus (HPV) in Women with Normal Endo-Cervical Cytology in Senegal
}

Babacar Faye ${ }^{1,2,3^{*}}$, Fatimata Diallo ${ }^{1}$, Hameth Sarr ${ }^{1}$, Pape Mbacké Sembene ${ }^{4}$ and Alioune Dièye ${ }^{3}$

${ }^{1}$ Laboratory of Molecular Biology, Military Hospital of Ouakam (HMO), BP 24221 Dakar-Ouakam, Senegal

${ }^{2}$ AIDS Program of the Senegalese Armed Forces, Senegal

${ }^{3}$ Service of Immunology, Department of Pharmacy, Faculty of Medicine, Pharmacy and Odontology of Cheikh Anta Diop University of Dakar, Senegal

${ }^{4}$ GenGesPop, Department of Animal Biology, Faculty of Science and Technology, Cheikh Anta Diop University, Dakar-Fann, Sénégal

DOI: $10.36347 / \mathrm{sajb} .2020 . \mathrm{v} 08 \mathrm{i} 02.002$

| Received: 19.01.2020| Accepted: 08.02.2020 | Published: 18.02 .2020

*Corresponding author: Dr. Babacar Faye

Abstract

Original Research Article

Background: Cervical cancer (CC) is a major public health problem worldwide. In Senegal, it is the first female cancer before breast cancer. Human papillomavirus (HPV) has been described as responsible for CC and is the most common sexually transmitted infection in the world. Low risk HPV (HPV-LR) including HPV 6 and HPV 11 are responsible for most of mild infections while among high-risk HPV (HPV-HR) including genotypes 16, 18, 45, 31, 33, 52, 58, 35 in order of frequency are involved in almost $90 \%$ of cervical cancer. Objective: The general objective is to do molecular genotyping of HPVs and to assess the prevalence of HPV types among Senegalese women. Materials and methods: The study was done on a population of 198 sexually active women with normal cytology. DNA extraction is carried out using endocervical samples stored in Abbott Cervi-Collect Specimen Collection Kit tubes with the Zymo Research DNA Viral $\mathrm{KIT}^{\mathrm{TM}}$, USA www.Zymoresearch.com. Molecular identification of the HPV genotypes (19 HPV-HR and 9 HPV-LR) was carried out by multiplex PCR with the Anyplex ${ }^{\mathrm{TM}}$ II HPV28 Detection kit from Seegene on a CFX96 ${ }^{\mathrm{TM}}$ Bio-Rad machine. Data analysis was performed by R Studio software (3.6.0), Pearson chi-square comparisons or Fisher's exact test. Odds Ratios were calculated to estimate the association between individual characteristics and HPV infection if P<5\%. Results: $64.65 \%$ (128/198) Women were infected with HPV. HPV-HR and HPV-LR had respective prevalences of $57.07 \%(113 / 198)$ and $34.34 \%(68 / 128) .37 .37 \%$ of the women presented a co-infection, that is to say hosting at least two genotypes. The most common genotypes were HPV56 (27.78\%), HPV68 (12.12\%), HPV52 (8.59\%), HPV31 (8.08\%), HPV58 and HPV82 (7.07\% each) in HPV-HR and among HPV-LR HPV 42 (14.14\%), HPV54 (8.08\%), HPV43 and HPV44 (5.05\%, each). HPV16 and HPV18 had a prevalence of $7.07 \%$ and 5.05\% respectively and HPV-6 and HPV-11 also had a prevalence of $4.54 \%$ and $0.51 \%$ respectively. Our results showed that there was an association between HPV infection, age, marital status and contraception. Conclusion: Our results show high prevalence of HPV HPV-HR and HPV-LR in our population of women with normal cytology. The number of co-infected women who harbored at least two genotypes was high. The non-vaccine genotypes are mainly identified (HPV56, HPV42, HPV68, HPV52, HPV31, HPV54 et HPV82). The HPV16 and HPV18 genotypes were present at a moderate level. The woman's marital status, the woman's age and contraception were associated with HPV infection. These results contribute to a better understanding of the molecular epidemiology of HPV in Senegal.

Keywords: HPV, Prevalence, Anyplex ${ }^{\mathrm{TM}}$ II HPV 28 Detection, Genotyping, Senegal.

Copyright @ 2020: This is an open-access article distributed under the terms of the Creative Commons Attribution license which permits unrestricted use, distribution, and reproduction in any medium for non-commercial use (NonCommercial, or CC-BY-NC) provided the original author and source are credited

\section{INTRODUCTION}

The main cause of cervical cancer is the persistence of human papilloma virus (HPV) infection. This persistence of HPV can lead to cellular abnormalities, which in the natural development of the disease can lead to cervical cancer [1]. Nowadays more than 189 genotypes of HPV have been identified among them 120 types are susceptible to infect humans and of which the 40 genotypes are responsible for genital infections [2]. The latter are classified according to their epidemiological association with cervical cancer. A distinction is made between low-risk HPV (HPV-LR) such as HPV types 6 and 11 can cause benign or low-grade changes in cervical cells, and are responsible for around $90 \%$ of genital warts [3] and high-risk HPV (HPV-HR), which can cause anal and genital cancers [4]. These HPV-HR are found in almost $100 \%$ of cervical cancers and in a variable proportion of other genital or oropharyngeal cancers. HPV-HR types 16 and 18 are found worldwide in around $70 \%$ of cancers linked to 
HPV [5]. Genotypes 16,18, 45, 31, 33, 52, 58, 35, in order of frequency, are involved in almost $90 \%$ of cervical cancers [6].

HPV infection is among the most common human viral infections around the world; about $80 \%$ of sexually active people will be infected at some point in their lives. Human-to-human transmission occurs mainly through direct contact; however, their transmission is not exclusively sexual [7].

About $10.4 \%$ of women with normal cytological results in the cervix are infected with HPV. The least developed regions were particularly the most affected in particular in Africa $(22.1 \%$ ), in Central America and Mexico (20.4\% each) compared to North America (11.3\%) to Europe (8.1\%) and Asia (8.0\%) [8]. The hypothesis of the link between genital HPV infections and cervical cancer was suggested in the early 1976 s and later confirmed by fundamental and epidemiological studies [9].

Each year, there are approximately 569847 new cases with an estimated 311400 deaths. Which makes cervical cancer (CC) a major public health problem worldwide [10]. It is the second most frequently diagnosed cancer and the third leading cause of death from cancer in women in developing countries [11]. In Senegal it is the first female cancer in 2018 with around 1876 new CCs diagnosed each year [12]. Although HPV infection is common, studies suggest that around $90 \%$ of infections disappear over the years [13]. Three types of prophylactic vaccines are available and have been developed based on epidemiological data from Western countries. They therefore targeted HPV types 6,11,16,18 and several other subtypes [14]. However, in our African countries other non-vaccine genotypes are revealed but which seems to pose a problem as shown by various studies carried out in an African environment [15]. Since HPV-HR infection is a cause of cervical cancer, HPV-HR detection tests based on the detection of viral DNA by molecular techniques have been proposed as a complementary tool to cervical cytology [16]. Large-scale use in specialized laboratories allows early management of HPV infections and effective prevention of cervical cancer.

The objective of our study was to do a molecular genotyping of HPVs and to assess their prevalence in a population of Senegalese women with normal endo-cervical cytology.

\section{MATERIALS AND METHODS Study Type and Population}

This descriptive and analytical cross-sectional study was carried out in the molecular biology laboratory of the Armed Forces AIDS Control Program at the Ouakam Military Hospital Dakar, Senegal, from February 2016 to May 2019. The target population was
198 women who came to undergo cervical cancer screening or prescription screening from various health facilities with free and informed consent. Each woman responded to a survey sheet collecting information on identity, socio-demographic parameters such as age, marital status abortion age of first sexual intercourse, the number of sexual partners, contraception has been filled. To be eligible women had to be sexually active and able to undergo a vaginal speculum examination.

\section{Samples}

198 endo-cervical samples were taken using a cytobrush by swabbing the endocervix. The cytobrush is then introduced into a transport tube of the Abbott multi-sample collection kit (Abbott GmbH Co. KG Max Plank, Germany) and the sample is stored at $-80^{\circ} \mathrm{C}$ before the test.

\section{DNA extraction and nanodrop DNA assay}

The extraction of viral DNA was done using the Zymo DNA kit $^{\text {TM }}$ Research, USA, www.zymoresearch.com according to the manufacturer's protocol of $200 \mu \mathrm{l}$ of endocervical sample. Viral DNA extract was analyzed using NanoDrop ${ }^{\mathrm{TM}}$ Lite [17] to assess its quality and quantity and then stored at $-20^{\circ} \mathrm{C}$ before PCR.

\section{Molecular Genotyping}

The molecular analysis was carried out by multiplex PCR with the Seegene Anyplex II HPV28 Detection kit on the CFX96 real-time Biorad machine according to the manufacturer's protocol. The Anyplex II HPV28 Detection method makes it possible to detect 28 HPV genotypes in vitro in cytological fluids or cervical samples. This technique makes it possible to detect genotyping and quantify individually $19 \mathrm{HPV}-\mathrm{HR}$ (16, $18,26,31,33,35,39,45,51,52,53,56,58,59,66,68$, $69,73,82)$ and 9 HPV-LR $(6,11,40,42,43,44,54,61$, 70 ) by using DPO (double priming oligonucleotide) and TOCE $^{\mathrm{TM}}$ (Tagging Oligonucleotide Cleavage and Extension) technology [18], a fragment of the $\beta$-globin gene was co-amplified as an internal control.

\section{Data entry and Analysis}

All information collected from the questionnaires was recorded in an Excel database. Data analysis was performed by R Studio software (3.6.0). Proportional comparisons were made using the Pearson chi-square test or the Fisher exact test.

The significance rate is $\mathrm{P}<5 \%$. Odds Ratios were calculated to estimate the association between individual characteristics and HPV infection and $\mathrm{P}<5 \%$.

\section{RESULTS \\ Prevalence of HPV in the general population} $64.65 \%(128 / 198)$ patients had an HPV infection (Table-1). The respective prevalence of HPV-HR and HPV-LR were $57.07 \%$ and $34.34 \%$. 
Multi-infection was present in $37.37 \%$ of women, that means hosting at least two HPV genotypes (Table-2).

\section{Identification of HPV genotypes in the study population}

Our study method makes it possible to detect 28 genotypes. We have described the most representative types of HPV in our study population. The genotypes HPV56, HPV42, HPV68 were the main viruses identified with a prevalence of $27.78 \%, 14.14 \%$ and $12.12 \%$. Secondly follow the genotypes HPV52 (8.59\%) HPV31 and HPV54 (8.08\%) and HPV58 and HPV82 $(7.07 \%)$. Due to their highly oncogenic nature, we are interested in the HPV16 and HPV18 genotypes and their prevalence was $7.07 \%$ and $5.05 \%$ respectively. Due to their strong presence in genital warts, types HPV6 and HPV 11 were also found with a prevalence of $4.54 \%$ and $0.51 \%$ (Table-2).

\section{Prevalence of HPV by age}

The median age of the patients was 43 years with extremes of 20 and 73 years. To study the age-HPV infection relationship, our cohort was classified into three groups. The prevalence of HPV was $67.9 \%, 51.8 \%$ and $79.7 \%$ respectively in age groups $<35$ years, [35-50[ and $\geq 50$ ans. Women aged $<35$ years and $\geq 50$ years were more infected than those aged between $35-50$ years $(\mathrm{p}=0.002)($ Table-1).

\section{Prevalence of HPV by marital status}

We evaluated the carrying of the HPV according to the marital status of the patient. The prevalence of HPV was $80 \%$ and $60.1 \%$ respectively for unmarried and married women. Prevalence of HPV was significantly higher in unmarried women, $(\mathrm{p}=0.01)$; $\mathrm{OR}=2.6$ (Table-1)

\section{Prevalence of HPV according to contraception}

The evaluation of the carrying of HPV according to contraception showed a prevalence of HPV of $73.8 \%$ and $47.06 \%$ respectively in women without contraception and in those using contraception. Women who did not use contraception were more susceptible to HPV than those who did use contraception $(\mathrm{p}=0.0002$; $\mathrm{OR}=3.2)($ Table-1).

\section{Prevalence of HPV by number of abortions}

An HPV carrying rate of $65.7 \%$ and $63.2 \%$ was detected in women without abortion and in women with a history of abortion. Abortion is not considered here to be associated with HPV infection rates in women $(\mathrm{p}=0.75)($ Table-1).

\section{Prevalence of HPV by ethnicity}

The relationship between the ethnic group and the carrying of the HPV-HR has been studied. Ethnic associations are grouped into three groups: Pulaars; Wolofs and others (Sérère, Jola, Soninké, Bambara etc.). The prevalence of HPV was $70.69 \%, 57.33 \%$ and $67.69 \%$ respectively among women of the Pulaars, wolofs and other ethnic groups. Ethnicity is not considered to be associated with HPV infection in women $(\mathrm{p}>0.23)($ Table-1).

Table-1: Prevalences of HPV as a function of socio-demographic parameters

\begin{tabular}{|c|c|c|c|c|}
\hline & Parameters $(\mathbf{N})$ & HPV n (\%) [IC 95\%] & $P$-value & OR [IC 95\%] \\
\hline & $\begin{array}{l}\text { Prevalence HPV } \\
(198)\end{array}$ & $\begin{array}{l}128(\mathbf{6 4 . 6 5}) \\
{[57.8-70.9]}\end{array}$ & - & - \\
\hline \multirow[t]{3}{*}{ Age } & {$[20-35[(56)$} & $\begin{array}{l}38(67.9) \\
{[54.8-78.6]}\end{array}$ & \multirow[t]{3}{*}{0.002} & $\begin{array}{l}0.51 \\
{[0.25-1.03]}\end{array}$ \\
\hline & {$[35-50[(83)$} & $\begin{array}{l}3(\mathbf{5 1 . 8 )} \\
{[41.2-62.2]}\end{array}$ & & 1 \\
\hline & $>50(59)$ & $\begin{array}{l}47(\mathbf{7 9 . 7}) \\
{[67.7-87.9]}\end{array}$ & & $\begin{array}{l}0.27 \\
{[0.13-0.59]}\end{array}$ \\
\hline \multirow[t]{2}{*}{ Marital status } & Non married (45) & $\begin{array}{l}36(\mathbf{8 0}) \\
{[66.2-89.1]}\end{array}$ & \multirow[t]{2}{*}{0.01} & \multirow[t]{2}{*}{$\begin{array}{l}2.6 \\
{[1.19-5.89]}\end{array}$} \\
\hline & Married (153) & $\begin{array}{l}92(\mathbf{6 0 . 1}) \\
{[52.2-67.5]}\end{array}$ & & \\
\hline \multirow[t]{2}{*}{ Contraception } & No (130) & $\begin{array}{l}96(\mathbf{7 3 . 8}) \\
{[65.7-80.6]}\end{array}$ & \multirow[t]{2}{*}{0.0002} & \multirow[t]{2}{*}{$\begin{array}{l}3.17 \\
{[1.71-5.88]}\end{array}$} \\
\hline & Yes (68) & $\begin{array}{l}32(\mathbf{4 7 . 0 6}) \\
{[35.6-58.8]}\end{array}$ & & \\
\hline \multirow[t]{2}{*}{ Abortion } & No (102) & $\begin{array}{l}67(\mathbf{6 5 . 7}) \\
{[56.05-74.18]}\end{array}$ & \multirow[t]{2}{*}{0.7} & \multirow[t]{2}{*}{-} \\
\hline & Yes (96) & $\begin{array}{l}61(\mathbf{6 3 . 5}) \\
{[53.57-72.48]}\end{array}$ & & \\
\hline \multirow[t]{3}{*}{ Ethnics } & Others (65) & $\begin{array}{l}44(67.69) \\
{[55.6-77.8]}\end{array}$ & \multirow[t]{3}{*}{0.23} & \multirow[t]{3}{*}{-} \\
\hline & Wolofs (75) & $\begin{array}{l}43(\mathbf{5 7 . 3 3}) \\
{[46.05-67.9]}\end{array}$ & & \\
\hline & Pulaars (58) & $\begin{array}{l}41(\mathbf{7 0 . 6 9 )} \\
{[57.99-80.82]}\end{array}$ & & \\
\hline
\end{tabular}

$\mathrm{N}=$ sample size (number), $\mathrm{n}=\mathrm{HPV}$ positive number 
Table-2: Prevalence of individualized HPV genotypes in the general population

\begin{tabular}{|c|c|c|c|c|}
\hline & Genotypes & Positives & $(\%)$ & IC à $95 \%$ \\
\hline \multirow[t]{20}{*}{ HPV high risks (HPV-HR) } & HPV-HR & 113 & 57.07 & {$[50.11-63.76]$} \\
\hline & HPV 16 & 14 & 7.07 & {$[4.26-11.52]$} \\
\hline & HPV 18 & 10 & 5.05 & {$[2.75-9.05]$} \\
\hline & HPV 26 & 0 & $\mathbf{0}$ & {$[0.00-1.90]$} \\
\hline & HPV 31 & 16 & 8.08 & {$[5.04-12.72]$} \\
\hline & HPV 33 & 10 & 5.05 & {$[2.77-9.05]$} \\
\hline & HPV 35 & 3 & 1.52 & {$[0.52-4.36]$} \\
\hline & HPV 39 & 2 & 1.01 & {$[0.28-3.61]$} \\
\hline & HPV 45 & 4 & 2.02 & {$[0.79-5.08]$} \\
\hline & HPV 51 & 4 & 2.02 & {$[0.79-5.08]$} \\
\hline & HPV 52 & 17 & 8.59 & {$[5.43-13.32]$} \\
\hline & HPV 53 & 8 & 4.04 & {$[2.06-7.77]$} \\
\hline & HPV 56 & 55 & 27.78 & [22.01-34.39] \\
\hline & HPV 58 & 14 & 7.07 & {$[4.26-11.52]$} \\
\hline & HPV 59 & 4 & 2.02 & {$[0.79-5.08]$} \\
\hline & HPV 66 & 24 & 12.12 & {$[8.28-17.4]$} \\
\hline & HPV 68 & 24 & 12.12 & {$[8.28-17.4]$} \\
\hline & HPV 69 & 7 & 3.54 & {$[1.72-7.12]$} \\
\hline & HPV 73 & 9 & 4.55 & {$[2.41-8.41]$} \\
\hline & HPV 82 & 14 & 7.07 & {$[4.26-11.52]$} \\
\hline \multirow[t]{11}{*}{ HPV low risks (HPV-LR) } & HPV-LR & 68 & 34.34 & [28.08-41.20] \\
\hline & HPV 6 & 9 & 4.54 & {$[2.41-8.41]$} \\
\hline & HPV 11 & 1 & 0.5 & {$[0.09-2.81]$} \\
\hline & HPV 40 & 2 & 1.01 & {$[0.28-3.61]$} \\
\hline & HPV 42 & 28 & 14.14 & [9.97 - 19.68] \\
\hline & HPV 43 & 10 & 5.05 & {$[2.77-9.05]$} \\
\hline & HPV 44 & 10 & 5.05 & {$[2.77-9.05]$} \\
\hline & HPV 54 & 16 & 8.08 & {$[5.03-12.72]$} \\
\hline & HPV 61 & 5 & 2.53 & {$[1.08-5.77]$} \\
\hline & HPV 70 & 7 & 3.54 & {$[1.72-7.12]$} \\
\hline & co-infection & 74 & 37.37 & [30.93-44.29] \\
\hline
\end{tabular}

\section{DISCUSSION}

The prevalence of HPV in our general population is $64.65 \%$. This rate is very high compared to the average in West Africa which was $27.8 \% \%$ [19], however it is roughly equal to that described in Gabon $(60 \%)$ [20]. It is much higher than those described in Senegal (12.7\%) [21] and in Guinea (50.8\%) [22], however a higher rate $(76 \%)$ has been described in Morocco [23]. The variation in prevalence between countries may be linked to the difference in sexual practices and education. The difference in molecular techniques used in studies of HPV (panel of genotypes detected) may explain the variation in prevalence. HPV-HR genotypes were detected in $57.07 \%$ in our series. This rate is higher than the $13.6 \%$ reported in the Fiji Islands [24] but it is lower than the $72.6 \%$ described in Burkina Faso [25]. 37.37\% of women had multiple infections. This multi-infection rate is above the $30 \%$ described in Senegal [26] but a higher rate of $77.42 \%$ has been described in Colombia [27]. These different rates may indicate that multiple infections are a common phenomenon since the modes of HPV transmission are identical. The most common genotypes in the population were HPV56 (27.78\%) HPV68 (12.12\%), HPV52 (8.59\%), HPV31 (8.08\%), HPV82 (7.07\%) among HPV-HR and HPV42 (14.14\%) followed by HPV54 $(8.08 \%)$ for HPV-LR. These results differ from those found in Senegal within the framework of a study carried out in five regions which had found a predominance of HPV 52 and 58 [28], and those found in Ethiopia where they had HPV16 followed by HPV35, HPV56, HPV58, HPV18, HPV31, HPV39, HPV45, HPV59 and HPV68 [29]. In our series, non-vaccine genotypes were predominant as in most Sub-Saharan countries Ouedraogo et al., [24] and provide the risk of carcinoma of the cervix 2.94 times higher, [30]. HPV16 and HPV18 deserve special attention because they are involved in $70 \%$ of cervical cancers [31] in the whole world. Genotypes HPV16 and HPV18 had a prevalence of $7.07 \%$ and $5.05 \%$ respectively. These rates are lower than those found in Asia [32]. The socio-demographic factors of the patients and their relationship with the carriage of HPV in women were evaluated. Our results showed that there was an association between HPV infection and age $(\mathrm{p}=0.002)$. 
Women aged $\geq 50$ years and those aged $<35$ were the most infected and this U-shaped distribution was found in French Guiana [33] and in other countries by cross-sectional and cohort studies, with a first peak in women under 30 and a second peak in women 55 to 64 [34-36].

An association between HPV infection and marital status has also been shown $(p=0.01)$. Single women were more infected with HPV. These results are in agreement with numerous studies notably those found in Senegal [21], Ouagadougou [25] and in Poland [37]. A strong association between HPV infection and contraception has also been shown $(\mathrm{p}=0.0002)$. Women who did not use any contraceptive method were more sensitive to HPV than others; these results corroborate those found in Burkina Faso [38]. However, our results differ from those found by numerous studies, which showed through numerous epidemiological studies that contraception was a risk factor for users $[39,40]$.

Our results showed that there was no association between HPV infection and the number of abortions by ethnicity.

\section{CONCLUSION}

Our results show high prevalence of HPV, HPV-HR and HPV-LR, in our population of women with normal endo-cervical cytology. The number of co-infected women who harbored at least two genotypes was high. The non-vaccine genotypes are mainly identified (HPV56, HPV42, HPV68, HPV52, HPV31, HPV54 and HPV82). The HPV16 and HPV 18 genotypes responsible for $70 \%$ of cervical cancers were present at a moderate level. There was association between HPV infection and, age, marital status and contraception of women.

\section{ACKNOWLEDGMENTS}

The authors are grateful to the Department of Defense HIV/AIDS Prevention Program (DHAPP) and Africare for their support of molecular biology equipment. We would like to extend our acknowledgement to Babacar Diouf for his revision of the manuscript.

\section{REFERENCES}

1. Lessard J, Lessard J, Moqadem K, Goggin P, Mayrand $\mathrm{MH}$, Boulanger J. Comparaison des stratégies de dépistage du cancer du col de l'utérus avec le test de détection des virus du papillome humain (test VPH) ou la cytologie gynécologique (test Pap) Québec, Qc: INESSS; 2017 http://www.santecom.qc.ca/Bibliothequevirtuelle/I NESSS/9782550788805.pdf

2. Bernard HU, Burk RD, Chen Z, Van Doorslaer K, Zur Hausen H, de Villiers EM. Classification of papillomaviruses (PVs) based on $189 \mathrm{PV}$ types and proposal of taxonomic amendments. Virology. 2010 May 25;401(1):70-9.

3. Bosch FX, Lorincz A, Muñoz N, Meijer CJ, Shah $\mathrm{KV}$. The causal relation between human papillomavirus and cervical cancer. Journal of clinical pathology. 2002 Apr 1;55(4):244-65.

4. Dunne EF, Unger ER, Sternberg M, McQuillan G, Swan DC, Patel SS, Markowitz LE. Prevalence of HPV infection among females in the United States. Jama. 2007 Feb 28;297(8):813-9.

5. Louie K, Didelot MN, Damay A, Nagot N, Mayaud P, Segondy M. Papillomavirus humains (HPV) et cancers associés: aspects épidémiologiques. /data/revues/1773035X/00380405/27/

https://www.em-consulte.com/en/article/185831

6. Duport DN. Données épidémiologiques sur le cancer du col de l'utérus État des connaissances Actualisation 2008. Inst Natl Veille Sanit. 2008;33.

7. Bouassa RSM, Prazuck T, Lethu T, Meyé JF, Bélec L. Cervical cancer in sub-Saharan Africa: an emerging and preventable disease associated with oncogenic human papillomavirus. Med Sante Trop. 2017; 27(1):16-22.

8. Mutombo AB, Benoy I, Tozin R, Bogers J, Van geertruyden J-P, Jacquemyn Y. Prevalence and Distribution of Human Papillomavirus Genotypes Among Women in Kinshasa, The Democratic Republic of the Congo. Journal Glob Oncol. 16 juill 2019;(5):1-9.

9. Mougin C, Mo L, Dalstein V. Natural history of papillomavirus infections. Rev Prat. 15 nov 2006;56(17):1883-9.

10. Ferlay J, Colombet M, Soerjomataram I, Mathers C, Parkin DM, Piñeros M, Znaor A, Bray F. Estimating the global cancer incidence and mortality in 2018: GLOBOCAN sources and methods. International journal of cancer. $2019 \mathrm{Apr}$ 15;144(8):1941-53.

11. Torre LA, Bray F, Siegel RL, Ferlay J, LortetTieulent J, Jemal A. Global cancer statistics, 2012. CA: a cancer journal for clinicians. 2015 Mar;65(2):87-108.

12. Bruni L, Barrionuevo-Rosas L, Albero G, Serrano B, Mena M, Gómez D, Muñoz J, Bosch F, de Sanjosé S. ICO/IARC Information Centre on HPV and Cancer (HPV Information Centre). human papillomavirus and related diseases in the world. Summary report 27 July 2017.

13. Franco EL, Villa LL, Sobrinho JP, Prado JM, Rousseau MC, Désy M, Rohan TE. Epidemiology of acquisition and clearance of cervical human papillomavirus infection in women from a high-risk area for cervical cancer. The Journal of infectious diseases. 1999 Nov 1;180(5):1415-23.

14. Wang Z, Li Z, Li J, Wang C, Wang W, Hao M, Zhao C. Prevalence and distribution of HPV genotypes in 1387 women with cervical intraepithelial neoplasia $2 / 3$ in Shanxi Province, China. Journal of Cancer. 2018;9(16):2802. 
15. Blossom DB, Beigi RH, Farrell JJ, Mackay W, Qadadri B, Brown DR, Rwambuya S, Walker CJ, Kambugu FS, Abdul-Karim FW, Whalen CC. Human papillomavirus genotypes associated with cervical cytologic abnormalities and HIV infection in Ugandan women. Journal of medical virology. 2007 Jun;79(6):758-65.

16. Min KJ, Lee YJ, Suh M, Yoo CW, Lim MC, Choi J, Ki M, Kim YM, Kim JW, Kim JH, Park EW. The Korean guideline for cervical cancer screening. Journal of gynecologic oncology. 2015 Jul $1 ; 26(3): 232-9$.

17. ThermoFisher ScientificTM. NanoDrop LITE. 2012.

http://www.thermofisher.com/order/catalog/produ ct/ND-2000

18. Agee S. High-Multiplex Real-Time PCR Design [Internet]. GEN-Genetic Engineering and Biotechnology News. 2016 https://www.genengnews.com/magazine/269/highmultiplex-real-time-pcr-design/

19. Ogembo RK, Gona PN, Seymour AJ, Park HS, Bain PA, Maranda L, Ogembo JG. Prevalence of human papillomavirus genotypes among African women with normal cervical cytology and neoplasia: a systematic review and meta-analysis. PloS one. 2015;10(4):e0122488.

20. Assoumou SZ, Mbiguino AN, Mabika BM, Ogoula SN, El Mzibri M, Khattabi A, Ennaji MM. Human papillomavirus genotypes distribution among Gabonese women with normal cytology and cervical abnormalities. Infectious agents and cancer. 2016 Dec;11(1):2.

21. Faye B, Sarr H, Guèye-Diouf $S$, Sembène M, Dièye A. Human Papillomavirus High-Risk Molecular Identification Among Senegalese Women. J Mol Genet Med. 2019; 13(3):6.

22. Keita N, Clifford GM, Koulibaly M, Douno K, Kabba I, Haba M, Sylla BS, Van Kemenade FJ, Snijders PJ, Meijer CJ, Franceschi S. HPV infection in women with and without cervical cancer in Conakry, Guinea. British journal of cancer. $2009 \mathrm{Jul} ; 101(1): 202-8$.

23. Birrou K, Tagajdid MR, Elkochri S, Abi R, Zouhdi M, Mrani S. Human papillomavirus genotype prevalence and distribution among Moroccan women. 2015.

24. Foliaki S, Brewer N, Pearce N, Snijders PJ, Meijer CJ, Waqatakirewa L, Clifford GM, Franceschi S. Prevalence of HPV infection and other risk factors in a Fijian population. Infectious agents and cancer. 2014 Dec;9(1):14.

25. Ouedraogo CM, Djigma FW, Bisseye C, Sagna T, Zeba M, Ouermi D, Karou SD, Pietra V, Buelli F, Ghilat-Avoid-Belem NW, Sanogo K. Épidémiologie et caractérisation des génotypes de papillomavirus humain dans une population de femmes à Ouagadougou. Journal de gynécologie obstétrique et biologie de la reproduction. 2011 Nov 1;40(7):633-8.

26. Soumboundou M, Thiam I, Doh K, Dieng MM, Dial C, Malesys C, Guaye PM, Thioune AZ, Dem A, Diarra M, Lafrasse CR. HPV Genotypes of Senegalese Women Attending Radiotherapy. Open Journal of Biophysics. 2018 Mar 30;8(2):85-94.

27. Quinónez-Calvache EM, Ríos-Chaparro DI, Ramírez JD, Soto-De León SC, Camargo M, Del Río-Ospina L, Sánchez R, Patarroyo ME, Patarroyo MA. Chlamydia trachomatis Frequency in a Cohort of HPV-infected Colombian women. PloS one. 2016;11(1).

28. Mbaye EH, Gheit T, Dem A, McKay-Chopin S, Toure-Kane NC, Mboup S, Tommasino M, Sylla BS, Boye CS. Human papillomavirus infection in women in four regions of Senegal. Journal of medical virology. 2014 Feb;86(2):248-56.

29. Wolday D, Derese M, Gebressellassie S, Tsegaye B, Ergete W, Gebrehiwot Y, Caplan O, Wolf DG, Maayan S. HPV genotype distribution among women with normal and abnormal cervical cytology presenting in a tertiary gynecology referral Clinic in Ethiopia. Infectious agents and cancer. 2018 Dec 1;13(1):28.

30. Senapati R, Nayak B, Kar SK, Dwibedi B. HPV genotypes co-infections associated with cervical carcinoma: Special focus on phylogenetically related and non-vaccine targeted genotypes. PLoS One. 2017;12(11):e0187844.

31. Louie K, Didelot MN, Damay A, Nagot N, Mayaud P, Segondy M. Papillomavirus humains (HPV) et cancers associés: aspects épidémiologiques. Revue francophone des laboratoires. 2008 Oct 1;2008(405):27-34.

32. Harano T, Okada S. Prevalence of high-risk human papillomavirus (HR-HPV) infection among women with normal and abnormal cervical cytology in Myanmar. Acta Medica Okayama. 2014;68(2):79-87.

33. Dufit V, Adenis A, Douine M, Najioullah F, Kilie O, Molinié V, Catherine D, Thomas N, Deshayes JL, Brousse P, Carles G. Épidémiologie de l'infection à papillomavirus humains chez les femmes âgées de 20 à 65 ans résidant dans des communes isolées de Guyane française: adapter l'action au territoire. Bull D'épidémiologie Hebd INVS. 2016; 34:11.

34. Cutts FT, Franceschi S, Goldie S, Castellsague XD, De Sanjose S, Garnett G, Edmunds WJ, Claeys P, Goldenthal KL, Harper DM, Markowitz L. Human papillomavirus and HPV vaccines: a review. Bulletin of the World Health Organization. 2007;85:719-26.

35. Bruni L, Diaz M, Castellsagué M, Ferrer E, Bosch FX, de Sanjosé S. Cervical human papillomavirus prevalence in 5 continents: meta-analysis of 1 million women with normal cytological findings. 
Babacar Faye et al., Sch Acad J Biosci, Feb, 2020; 8(2): 23-29

Journal of Infectious Diseases. 2010 Dec 15;202(12):1789-99.

36. De Sanjosé S, Diaz M, Castellsagué X, Clifford G, Bruni L, Muñoz N, Bosch FX. Worldwide prevalence and genotype distribution of cervical human papillomavirus DNA in women with normal cytology: a meta-analysis. The Lancet infectious diseases. 2007 Jul 1;7(7):453-9.

37. Bardin A, Vaccarella S, Clifford GM, Lissowska J, Rekosz M, Bobkiewicz P, Kupryjańczyk J, Krynicki R, Jonska-Gmyrek J, Danska-Bidzinska A, Snijders PJ. Human papillomavirus infection in women with and without cervical cancer in Warsaw, Poland. European Journal of Cancer. 2008 Mar 1;44(4):557-64.

38. Zohoncon TM, Bisseye C, Djigma FW, Yonli AT, Compaore TR, Sagna T, Ouermi D, Ouédraogo
CM, Pietra V, Nikiéma JB, Akpona SA. Prevalence of HPV high-risk genotypes in three cohorts of women in Ouagadougou (Burkina Faso). Mediterranean journal of hematology and infectious diseases. 2013;5(1): e2013059 e2013059.

39. Vallée JP, Baqué-Gensac AM, Bergua G, Grall JC. La contraception orale augmente-t-elle le risque de cancer du col de $1^{\prime}$ utérus?. Médecine. 2008 Jan $1 ; 4(1): 8$

40. Marks M, Gravitt PE, Gupta SB, Liaw KL, Kim E, Tadesse A, Phongnarisorn C, Wootipoom V, Yuenyao P, Vipupinyo C, Rugpao S. The association of hormonal contraceptive use and HPV prevalence. International journal of cancer. 2011 Jun 15;128(12):2962-70. 